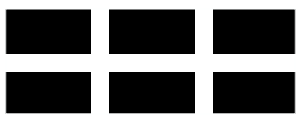

ThE William DAVIDSON INSTITUTE AT THE UNIVERSITY OF MICHIGAN BUSINESS SCHOOL

Wage Determination Under Communism and In Transition: Evidence from Central Europe

\author{
By: Swati Basu, Saul Estrin and Jan Svejnar
}

William Davidson Institute Working Paper Number 717

August 2004 


\title{
Wage Determination Under Communism and In Transition: Evidence from Central Europe
}

\author{
by \\ Swati Basu, McGill University \\ Saul Estrin, London Business School \\ Jan Svejnar, University of Michigan
}

July 2004

In undertaking the research for this paper, Saul Estrin and Jan Svejnar were in part supported by World Bank research grants on Enterprises in Transition and Labor Markets in Transition, respectively, and by ACE PHARE grant No. P96-6095-R. Svejnar in part also benefited from NSF grants Nos. SBR 951-2001 and SES-921-3310. The authors would like to thank Olivier Blanchard, Tito Boeri, Simon Commander, George Johnson, and participants of seminars at Princeton University, the London Business School and, University of Pittsburgh. They are also indebted to Lubomir Lizal, Miroslav Singer, Lina Takla, and Chris Walters for valuable computer assistance. 


\begin{abstract}
Using large firm-level data sets from the Czech Republic, Slovakia, Poland and Hungary, we show that the wage behavior of firms changed considerably as these economies launched their transitions to a market system. We find evidence of worker sharing in their enterprise rents and losses at the end of the communist period in some economies and within a year after the launching of the transition, we find rent sharing in all of them. Using the Czech and Slovak data we show that the state-owned enterprises (SOEs) that existed under communism and survived allow for less worker rent-sharing than other firms. We also test for the presence of a wage curve and with the exception of Slovakia we do not find a significant association between local unemployment and wages. Finally, we do not find significant effects of firm ownership on wages.
\end{abstract}




\section{Introduction}

Our aim in this paper is to provide a comparative empirical analysis of wage determination at the enterprise level in the Czech Republic, Hungary, Poland and Slovakia as these economies moved from central planning in a transition towards a market economy. We use large panels of annual data from the late 1980's to the 1990's to show how wage setting in firms altered as the economic system changed. Our main purpose is to explore whether workers shared in firm-specific rents and losses under communism and during the transition. This question is of interest because wages were set relatively rigidly across firms under central planning, but this lack of a relationship between a firm's performance and its workers' earnings was presumably waning as communism collapsed. Indeed, the issue of power of worker-insiders and firm-specific wage setting has arisen in many policy discussions since the start of the transition. (see e.g. World Bank, 1996, Barr et al 1994 and Svejnar,1997). The present paper complements Basu, Estrin and Svejnar's (2004) study of employment setting in these transition economies.

Our analysis suggests that wages did in fact vary with enterprise performance at the end of the communist period in Poland (where the Solidarity trade union was an important force) and to a lesser extent also in Slovakia (which had a more liberal and flexible political system in than the Czech Republic). However, there was no relationship between wages and performance under communism in the Czech Republic and Hungary. Yet, within a year after the launching of the transition, we find that worker incomes started to vary significantly with enterprise performance in all four Central European countries. In this context, we have also tested for the presence of a “wage curve” -- variation of wages with local unemployment (Blanchflower and Oswald, 1994) and, with the exception of Slovakia, we do not find a significant association. This lack of support for the wage curve hypothesis is interesting in view of the wide variation in the local unemployment rate across districts and over time.

The four Central and Eastern European economies in our study all experienced similar cumulative declines in GDP in the early 1990's of between $17.5 \%$ and $20 \%$, before growth resumed (see EBRD, 2003)). However, as Basu, Estrin and Svejnar (2004) note, the countries responded to this output drop differently in terms of employment and wage adjustment. In the Czech Republic, employment fell by 9\% but real product wages by 24\% from 1990-1992. In contrast, employment fell by $20.5 \%$ but real wages rose in Hungary by $17 \%$. The figures for 
Poland were $11 \%$ and $0.5 \%$ and for Slovakia 13.5 and $21 \%$, respectively. In addition to the decline in demand as a consequence of stabilization policies (see Aslund, Boone and Johnson,1996), and supply side shocks (see Blanchard and Kremer 1997), there was a sharp hardening of budget constraints in this period. Subsidies to firms represented 25\% of GDP in Czechoslovakia in 1989, compared with 12\% in Hungary and 10.6\% in Poland. By the early 1990’s, the figures was reduced to between 3\% and 6\% of GDP in all four economies.

In the following section we outline our conceptual framework and estimating equations, and in the third section our econometric results. Conclusions are drawn in the fourth section.

\section{The Conceptual Framework and Estimating Equations}

We use Figure 1 to illustrate wage determination before and during the transition. For any firm, the competitive labor market outcome is given by employment $L^{*}$ at point $A$, with the marginal revenue product of labor $\mathrm{R}_{\mathrm{L}}$ equaling the competitive (market clearing) wage $\mathrm{W}_{\mathrm{c}}$. In a communist system, it is argued that planners kept wages low and sought to maintain full employment (see Blanchard et al, 1997). Hence one can conceptualize an efficient centrally planned system with full employment as one that induces firms to operate at point A in Figure 1, with workers paid the minimum acceptable wage and planners appropriating the maximum profit, given by the iso-profit curve $\Pi=$ Max.

However, the communist system had been partially reformed in Hungary and Poland prior to transition, partly as a result of pressure from workers and managers. It is therefore more appropriate to conceptualize the workings of the labor market in these economies as bargaining between planners, managers and workers. Depending on the preferences and relative power of these three parties, the wage-employment outcome could lie anywhere in the area AB'F' in Figure $1{ }^{1}$ Points $\mathrm{B}^{\prime}$ and $\mathrm{F}^{\prime}$ lie on the zero profit $(\Pi=0)$ iso-profit curve and reflect the maximization of income per worker and employment, respectively, subject to profit being zero and the wage being at least $\mathrm{W}_{\mathrm{c}}$. The contract curve $A B B$ ', which corresponds to the short run labor demand curve of a profit maximizing firm, reflects outcomes with varying emphasis on wages and profit (no emphasis on employment), while the horizontal contract curve AFF' corresponds to varying degrees of joint employment and profit maximization (no emphasis on

1 See e.g., McDonald and Solow (1981) and Svejnar $(1982,1986)$ for the underlying model. 
wages above $\mathrm{W}_{\mathrm{c}}$ ). The outcomes $\mathrm{C}^{\prime}, \mathrm{D}^{\prime}$ and $\mathrm{E}^{\prime}$ on the $\Pi=0$ iso-profit curve reflect varying degrees of emphasis on wages and employment (subject to zero profit). A set of intermediate outcomes where the planners appropriate a given level of profit are depicted by the iso-profit curve $\Pi=\alpha$ Max and the corresponding points B, C, D, E, and F. The socially efficient set of bargaining outcomes, corresponding to $\mathrm{R}_{\mathrm{L}}=\mathrm{W}_{\mathrm{c}}$ and various wage-profit combinations, lies on the vertical contract curve ADD'.

Firms in different countries are likely to have started the transition from different wageemployment-profit combinations and probably exhibited different original distribution of power among the planners, managers and workers. Moreover, depending on the form of macro stabilization, enterprise commercialization and privatization, the hardening of budget constraints, and redistribution of power among the government, managers and workers, the behavior of firms is likely to have evolved differently in different countries. In view of all these possible changes, it would be necessary to invoke very strong assumptions if one tried to identify the preferences of the government, managers and workers and their possible changes over time. Moreover, for our purposes this is unnecessary, since our goal is to assess whether wage setting behavior changed systematically as a result of the transition.

We allow for bargaining over both wages and employment, with the contract curve deviating from the marginal product curve of labor in relation to the weight that the bargainers place on employment relative to wages. In particular, following the conceptual frameworks of Brown and Ashenfelter (1986) and Prasnikar et al. (1994), we assume that worker preferences over wages and employment are given by a Stone-Geary function,

$$
\mathrm{U}=\mathrm{k}\left(\mathrm{W} / \mathrm{P}-\mathrm{W}^{\mathrm{a}} / \mathrm{P}\right)^{\alpha} \mathrm{L}^{(1-\alpha)},
$$

where $\mathrm{W}=$ the nominal wage, $\mathrm{L}=$ number of employers, $\mathrm{P}=$ the product price index, $\mathrm{W}^{\mathrm{a}}$ is the alternative (reservation) wage, and that the management (and possibly government) is interested in profit

$$
\pi=\mathrm{PQ}-\mathrm{WL}-\mathrm{H},
$$


where $\mathrm{H}$ is fixed non-labor cost. A Pareto- efficient contract that equates the marginal rate of substitution between wages and employment in these two objective functions (e.g., in a Nash bargaining context) yields the marginal revenue product condition

$$
\mathrm{PQ}_{\mathrm{L}}=\mathrm{W}-\gamma\left(\mathrm{W}-\mathrm{W}^{\mathrm{a}}\right)
$$

where $\gamma=(1-\alpha) / \alpha$ is the weight that the firm places on employment relative to wages. In the context of a particular production technology (e.g., CES) one can derive an employment equation of the form

$$
\ln L=\beta_{o}+\beta_{1} \ln Q+\beta_{2} X-\sigma(1-\gamma) \ln (\mathrm{W} / \mathrm{P})-\sigma \gamma \ln \left(\mathrm{W}^{\mathrm{a}} / \mathrm{P}\right),
$$

where $\sigma$ is the constant elasticity of substitution between labor and capital. ${ }^{2}$ Basu et al. (2004) estimate equation (1), following Brown and Ashenfelter (1986) in taking the alternative wage to be an inverse linear function of local unemployment and industry dummy variables.

In this paper, we focus on the second equation coming out of the bargaining model, namely the one concerning the determination of wages. This equation allows for the possibility that worker-insiders appropriate some of the enterprise-specific rents as their wages. Ideally, we would like to include as a regressor a variable such as net profit per worker (Svejnar, 1986), so as to reflect firm's rents that could potentially be appropriated by workers. Our data sets do not contain sufficient information to do so and we hence proxy firm's rents by firm's sales per employee $(\mathrm{Q} / \mathrm{L})$ and two-digit industry dummy variables. The wage equation therefore reflects the hypothesis that, in addition to exogenous factors, wages may depend on enterprise characteristics, such $\mathrm{Q} / \mathrm{L}$ and policy variables:

$$
\mathrm{W}=\mathrm{W}(\mathrm{Q} / \mathrm{L}, \mathrm{X}, \mathrm{Z})
$$

2 When the firm places no weight on employment $(\gamma=0)$, the coefficient on the alternative wage is zero and the specification reduces to the standard labor demand equation. When the firm places equal weight on wages and employment ( $\square=1$ ), the coefficient on the own wage is zero and employment is driven by the alternative wage. This is the case corresponding to the (socially efficient) vertical contract curve ADD' in Figure 1. For $\square>1$, one obtains forward sloping contract curves such as AEE' in Figure 1. 
where $\mathrm{X}=$ a vector of ownership, legal status, industry and regional variables and $\mathrm{Z}=$ a vector of relevant structural and policy variables that may affect wages in a given firm. The most important variable included in the $\mathrm{Z}$ vector is the local unemployment rate, which is included to test whether it exerts a negative effect on the wage outcomes. This "wage curve" hypothesis has received considerable attention in the market economies (see Blanchflower and Oswald, 1994) and we check if it is supported by the firm-level data during the transition from plan to market.

We estimate equation (2) in a dynamic form, using a first degree distributed lag model on consecutive two-year panels of data. The dynamic specification is desirable since the early transaction period was very volatile and it would be unreasonable to assume complete adjustment of variables within a single year. Using consecutive two-year panels to estimate a series of dynamic cross-section equations is motivated primarily by the high frequency of enterprise entry, exit and break up in the Czech Republic and Slovakia. In fact, we would lose the majority of our observations if we sought to estimate across the entire period. Using the short panels has the advantage that we can assess how the behavior of firms changed from the pre-transition period into the various phases of early transition. For each country we therefore use consecutive two-year panels of data and test for the stability of coefficients across the twoyear periods.

We specify equation (2) in loglinear form and introduce a general dynamic framework by allowing the left hand side variable and all the principal right hand side variables to enter in both current and one year lagged form. Formally this first degree general distributed lag model is specified for equation (2) as

$$
\begin{aligned}
& \text { 1n }(\mathrm{W} / \mathrm{P})_{\mathrm{t}}=\mathrm{a}_{\mathrm{O}}+\mathrm{a}_{1} 1 \mathrm{n}(\mathrm{Q} / \mathrm{L})_{\mathrm{t}}+\mathrm{a}_{2} 1 \mathrm{n}(\mathrm{Q} / \mathrm{L})_{\mathrm{t}-1} \\
& \quad+\mathrm{a}_{3} 1 \mathrm{n} \mathrm{X}_{\mathrm{t}}+\mathrm{a}_{4} 1 \mathrm{n} \mathrm{X}_{\mathrm{t}^{-1}}+\mathrm{a}_{5} 1 \mathrm{n} \mathrm{Z}_{\mathrm{t}}+\mathrm{a}_{6} 1 \mathrm{n} \mathrm{Z}_{\mathrm{t}^{-1} 1}+\mathrm{a}_{7} 1 \mathrm{n}(\mathrm{W} / \mathrm{P})_{\mathrm{t}-1}
\end{aligned}
$$

The short run elasticity of wages with respect to productivity is given by $a_{1}$ while the corresponding long run elasticity is given by the ratio of the two relevant polynominals in the lag operator, $\left(a_{1}+a_{2}\right) /\left(1-a_{7}\right)$. The short run and long run elasticity with respect to the other independent variables are defined analogously. Equation (3) represents a relatively general model within which one can test if the appropriate specification is a) a partial adjustment model, $\mathrm{a}_{2}=\mathrm{a}_{4}=\mathrm{a}_{6}=0$; $\left.\mathrm{b}\right)$ a static model $\mathrm{a}_{2}=\mathrm{a}_{4}=\mathrm{a}_{6}=\mathrm{a}_{7}=0$ or c $)$ a first difference fixed effects model $\left(\mathrm{a}_{2}=-\mathrm{a}_{1}\right.$, 
$\mathrm{a}_{4}=-\mathrm{a}_{3}, \mathrm{a} 6=-\mathrm{a}_{5}$ and $\mathrm{a}_{7}=1$ ). In our empirical work, we reject all the above restrictions a) c).

\section{Data and Econometric Results}

We use annual data from industrial enterprises in four important transition economies: the Czech Republic, Hungary, Poland and Slovakia. The data were collected from records that enterprises were legally required to submit to their country's Statistical Offices and Ministries of Finance. The Czech, Slovak and Polish data sets contain almost all industrial firms with twenty five or more workers. Except for the small firms, these three data sets provide an almost complete record of the transition of industrial firms in three key transition economies. The drawback is that it has been impossible to obtain these data for the later years as western-style protection of information took place. The Hungarian data come from a panel of one thousand largest firms, of which about 400 are industrial firms. The latter are the firms we use in the present analysis.

The data cover the period 1989-93 for the Czech Republic, 1989-92 for Slovakia, 198891 for Poland and, 1988-92 for Hungary. In Poland and Hungary, the transition was launched at the start of 1990, ${ }^{3}$ while in the Czech and Slovak Republics it was on January 1, 1991. Our data therefore enable us to chronicle the evolution of behavior of the Czech, Slovak, Polish and Hungarian firms before and during the early transition. In interpreting the estimated coefficients, it is important to remember that the transition process started at different dates in different countries. For the Czech and Slovak data our estimates cover the pre-transition period of 198990, the start of the transition (big bang) in 1990-91, and the early transition (1991-92 for Slovakia and 1991-92 as well as 1992-93 for the Czech Republic). For Poland, the estimates cover the pre-transition period of 1988-89, the start of the transition in 1989-90 and the early transition in 1990-91. Hungary had adopted many market oriented reforms already in the 1970s and 1980s. Nevertheless, it is generally assumed that the transition process accelerated in 1989 and 1990. Our estimates cover the pre-transition period of 1988-89, the launch of transition in 1989-90, and the early transition period of 1990-92.

\footnotetext{
3 In Hungary, the reform process dates as far back as 1968 and the transition changes that occurred at the end of the 1980s and early 1990s were hence less fundamental than those in the other countries (see e.g., Kornai, 1995).
} 
Before presenting our empirical results, we address three additional issues related to our data and methodology. First, like most large firm-level data sets, our data come in annual rather than quarterly or monthly frequency and annual data contain aggregation over time that smoothes short term changes in variables. Second, the need to use short panels of data prevents us from using more than one lag of variables in our specification. The first-degree distributed lag specification is limiting but this is a shortcoming that we simply cannot overcome in view of the severe loss of observations that we would face if we were to use longer panels of data. Moreover, most empirical studies of the transition labor markets do not go beyond a one-period lag structure. Third, while one may argue that during the planning period and during the output demand shock at the start of the transition the $\mathrm{Q} / \mathrm{L}$ variable is exogenous to the firm, the Hausman test suggests that in a number of instances $Q / L$ is endogenous to the firm decisionmaking and in those instances we instrument it. The instrumental variables that we use are district dummy variables, two digit industry dummy variables, preceding year value of enterprise assets interacted with industry dummy variables, firm ownership, and the current and lagged average values of sales, wages, and employment of firms in the neighboring three digit, as well as the average value of lagged assets of firms in the neighboring three digit industry. The neighboring three digit industry is the next three digit industry in the relation to the industry the firm belongs to, within the same two digit industry classification. In the case of the last three digit industry in the two-digit classification, the three digit industry classification that is the most similar is chosen. The industry and regional dummy variables are used as instruments to capture factors such as the technical and managerial error components of the underlying production function (Zellner, Kmenta and Dreze, 1966). Finally, by using as instruments the average values of variables from firms in the nearest three-digit industry within the same two-digit classification, we capture the effect of common external shocks to similar sub-industries within a given two-digit industry, while avoiding the correlation between the error term and regressors that may be brought about by the firm- and three-digit industry fixed effects (Kmenta, 1997, p. 360).

In Table 1 we present wage elasticities with respect to sales per worker (proxying for rent-sharing) and the local unemployment rate (reflecting the wage curve hypothesis). The elasticities correspond to the dynamic version of wage equation, which was estimated jointly 
with an employment equation (1). ${ }^{4}$ The estimated short-term elasticities in Table 1 indicate that in the pre-transition Czech Republic and Hungary there was virtually no association between wages and sales per worker, suggesting that under communism Czech and Hungarian workers did not share in rents. In contrast, in Poland and Slovakia, one observes a positive association between wages and sales per worker in the last years of the communist regime. This suggests that the market-oriented reforms, observed under communism in Hungary and Poland but not in the Czech and Slovak Republics, were not mirrored in wages adjusting to firm-specific conditions. Rather, the rise of Solidarity trade union in Poland and the more liberal and flexible political system in Slovakia as compared to the Czech Republic appear to be associated with firm-specific elements of rent-sharing. In the transition period, one finds a positive short-term elasticity of wages with respect to sales in all four countries. To the extent that the instrumented sales per worker provide a good proxy for the firms' ability to pay when industry-specific effects are controlled for, the estimates in Table 1 provide evidence that as soon as transition started workers' wages contained a short-term link to firm-specific rents.

The wage curve hypothesis is reflected in an expected negative coefficient on unemployment in the wage equation. The hypothesis receives support in Slovakia in 1991-92, but it is uniformly rejected in the Czech Republic and Hungary. In Poland, the coefficient is statistically significant and of the predicted sign in 1991, but the size of the coefficient is too small to be economically significant. Hence, despite the significant variation in the local unemployment rate, the wage curve hypothesis receives very little support from our firm-level data.

While the Polish and Hungarian data sets contain almost exactly the same firms for the entire time period, the data from the Czech Republic and Slovakia indicate that the turnover of firms was considerable. Since the latter data sets comprise virtually the entire population of existing firms, this turnover points to entry of new firms and the disintegration of existing ones. The high turnover of firms enables us to test whether the SOEs that existed before and survived into transition behaved differently from the population of industrial firms as a whole, i.e.,

\footnotetext{
4 See Basu, Estrin, Svejnar, 2004, for details of the employment equation, which was also instrumented using the IVs described above. The complete set of parameter estimates and diagnostic statistics related to this table may be obtained from the authors upon request.
} 
including the new entrants.5

In Table 2 we report estimates of the wage elasticities for the balanced panel of surviving SOEs only. By comparing these results to those in Table 1, we can investigate whether SOEs that survived through the early years of transition determined wages in a different way to the population of firms as a whole including new firms. The wage elasticities reported in Table 2 are significantly smaller in both countries than those reported for all firms in Table 1. Hence in both Czech and Slovak firms, we find that surviving SOEs limited rent sharing more than in the entire population of firms. This implies that, for a given exogenous shock, adjustment of wages was less in the state owned sector than in the newly formed private sector, which suggests that in the early transition the state was still to some extent controlling wages across the state owned firms.

We also explored the effects of ownership and legal statues on wage determination. At the macro economic level, one observes that in the 1990s some of the transition economies that engaged in rapid privatization (e.g. Czech republic and Russia) registered low or negative rates of growth while others (e.g. Lithuania and Slovakia) grew relatively fast (see Bennett, Estrin, Maw and Urga, 2003). Similarly among transition countries that have proceeded slowly with privatization, some have grown rapidly (e.g. Poland and Slovenia) and others have had a mixed record (e.g. Bulgaria and Romania). Our estimates (not reported in Tables 1 and 2), suggest that neither ownership nor legal status (commercialization) of firms have a systematic effect on wages, ceteris paribus. We tested for those effects by including a number of dummy variables for ownership and legal status in the wage regressions but find little systematic evidence of an impact from ownership or legal status on wages. We find private ownership to be associated with higher wages in Poland and Slovakia during the later years for which we have data on transition in these economies (1990 and 1991 for Poland and 1992 for Slovakia) and in the middle year (1992) of our transition data period in the Czech Republic. However, we find no effect of private ownership on wages in the Czech Republic in 1991 and 1993. Our three-country evidence hence indicates that private firms paid higher wages after the "big bang” (1991 in Poland and 1992 in the Czech and Slovak Republics), but the Czech data suggest that this effect was temporary. Our findings are consistent with Munich, Svejnar and Terrell's (1999) estimates of an insignificant

5 In 1991, the surviving SOEs represented around one quarter of the Czech and one third of the Slovak firms in our sample. 
wage effect of firm ownership within a human capital earnings function in the Czech Republic, but not with Dobbelaere’s (2004) estimates for Bulgaria.

\section{Conclusions}

Using large firm-level data sets from the Czech Republic, Slovakia, Poland and Hungary, we show that the wage behavior of firms displayed considerable changes as these economies abandoned central planning and launched their transitions to a market system. We find evidence of worker sharing in their enterprise rents and losses at the end of the communist period in Poland (where the Solidarity trade union was an important force) and to a lesser extent also in Slovakia (where the communist regime was more liberal and flexible than in the Czech Republic). However, the phenomenon is undetectable at the end of communism in the Czech Republic and Hungary. The four sets of estimates suggest that market-oriented economic liberalization under communism did not uniformly extend into the labor market. Yet, within a year after the launching of the transition, we find that worker incomes started to vary significantly with enterprise performance in all four Central European countries that we study. We have also tested for the presence of a "wage curve" (variation of wages with local unemployment) and with the exception of Slovakia we do not find a significant association between local unemployment and wages. This lack of support for the wage curve hypothesis is particularly interesting in view of the wide variation in the local unemployment rates across districts and over time.

The Czech and Slovak data enable us to examine whether the state-owned enterprises (SOEs) that existed under communism and survived during the transition behave differently than the newly created firms or firms that were spun off from the old SOEs. In both republics, the SOEs allow for less worker rent-sharing than other firms.

Our final set of results relates to wage effects of enterprise ownership and legal status. Enterprise restructuring has been seen as a key element of a successful transition, with commercialization (change of a firm's legal status) and privatization being the principal factors bringing about the needed restructuring. We find that private firms in the Czech Republic, Slovakia and Poland paid higher wages immediately after the start of the transition, but the longer-period Czech micro-data suggest that this effect dissipated later on. The lack of detectable 
ownership effects points to the importance of examining the part played by complementary measures such as the introduction of effective corporate governance and competition. 


\section{References}

Aslund, A., P. Boone and S. Johnson, (1996) "How to Stabilize: Lessons from Post-Communist Countries," Brookings Papers on Economic Activity, No. 1, pp. 217-313.

Barr, N (1994), (ed) "Labor Markets and Social Policy in Central and Eastern Europe: The Transition and Beyond, " New York and Oxford: Oxford University Press

Basu, S, S. Estrin and J. Svejnar, (2004), "Employment Determination in Enterprises under Communism and in Transitional: Evidence from Central Europe," forthcoming in the Industrial and Labor Relations Review.

Bennett, J., S. Estrin, J. Maw and G. Urga, (2003) "Privatization Methods and Economic Growth,” Working Paper, London Business School.

Blanchard, O. and M. Kremer, (1997) “Disorganization,” Quarterly Journal of Economics, Vol. 112, No.4, 1091-1126.

Blanchflower, D.G. and A.J.Oswald (1994): The Wage Curve, Cambridge, MA and London: MIT Press, 1995.

Brown, J. and O. Ashenfelter (1986): “Testing the Efficiency of Employment Contracts,” Journal of Political Economy, 94:3, Part 2, 540-587.

Dobbelaere, S., (2004) “Ownership, Firm Size and Rent Sharing in Bulgaria,” Labor Economics, Vol. 11, No. 2, pp. 165-189.

European Bank for Reconstruction and Development, 1998 Transition Report, 1999 Transition Report and 2003 Transition Report 
Kornai, Janos (1995): Highway and Byways: Studies on Reform and Postcommunist Transition, Cambridge, MA: MIT Press.

Munich, D., J. Svejnar and K. Terrell (1999) "Returns to Human Capital Under the Communist Wage Grid During Communism and in the Transition to Capitalism: Retrospective Evidence from Czech Micro Data,” The William Davidson Institute Working Paper No. 272, University of Michigan Business School, forthcoming in the Review of Economics and Statistics, Feb. 2005.

Prasnikar, J., J. Svejnar, D. Mihaljek and V. Prasnikar. (1994): "Behavior of Participatory Firms in Yugoslavia: Lessons for Transforming Economies," Review of Economics and Statistics, November.

Svejnar, J., (1997) "Pensions in the Former Soviet Bloc: Problems and Solutions," The Coming Global Pension Crisis, Council on Foreign Relations, New York

Svejnar, J. (1982) "On the Theory of a Participatory Firm,” Journal of Economic Theory, Vol. 27, No. 2, August, pp. 313-330.

Svejnar, J. (1986): "Bargaining Power, Fear of Disagreement and Wage Settlements: Theory and Evidence from U.S. Industry.” Econometrica, Vol. 54, pp. 1055-1078.

World Bank, “The World Development Report,” 1996.

Zellner, A., J. Kmenta and J. Dreze (1966): "Specification and Estimation of CobbDouglas Production Models,” Econometrica, Vol. 34, Oct. pp.784-95. 


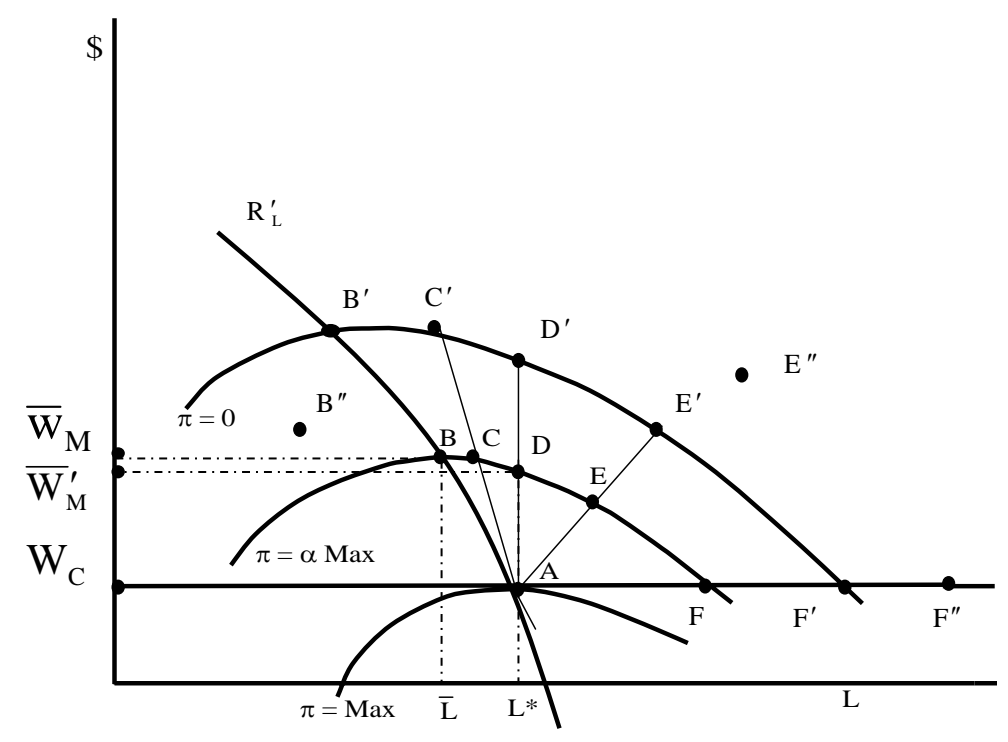

Figure 1 


\begin{tabular}{l} 
Table 1: Wage Elasticities with Respect to Sales per Worker and Local Unemployment: \\
3SLS Estimated on Unbalanced Panels \\
(Values in Parentheses are Standard Errors) \\
\hline \\
\hline
\end{tabular}




\begin{tabular}{|c|c|c|c|c|}
\hline & $\begin{array}{l}\text { Estimated } \\
\text { Parenthes }\end{array}$ & $\begin{array}{l}\text { Balanced P } \\
\text { Ire Standar }\end{array}$ & $\begin{array}{l}\text { s } \\
\text { rors) }\end{array}$ & \\
\hline & $1989-90$ & $1990-91$ & $1991-92$ & 1992-93 \\
\hline Czech Republic & & & & \\
\hline Short-term & $.068^{\mathrm{a}}$ & $.130^{\mathrm{a}}$ & $.155^{\mathrm{a}}$ & $.085^{b}$ \\
\hline & $(.013)$ & $(.030)$ & $(.054)$ & $(.041)$ \\
\hline Long-term & .052 & -.433 & .180 & .057 \\
\hline & $(.046)$ & $(.541)$ & $(.161)$ & $(.116)$ \\
\hline Unemployment & n.a. & -.273 & -.299 & -.162 \\
\hline & & $(.428)$ & $(.442)$ & $(.332)$ \\
\hline Slovak Republic & & & & \\
\hline Sales per worker & & & & \\
\hline Short-term & $.103^{\mathrm{a}}$ & $.101^{\mathrm{a}}$ & $.185^{\mathrm{a}}$ & \\
\hline & $(.030)$ & $(.023)$ & $(.072)$ & \\
\hline Long-term & n.a & $.650^{\mathrm{C}}$ & $.197^{6}$ & \\
\hline & & $(.352)$ & $(.087)$ & \\
\hline Unemployment & n.a & -.124 & $-.391^{b}$ & \\
\hline & & $(.239)$ & $(.171)$ & \\
\hline
\end{tabular}




\section{DAVIDSON INSTITUTE WORKING PAPER SERIES - Most Recent Papers}

The entire Working Paper Series may be downloaded free of charge at: www.wdi.bus.umich.edu

CURRENT AS OF 8/2/2004

\begin{tabular}{|c|c|c|}
\hline Publication & Authors & Date \\
\hline $\begin{array}{l}\text { No. 717: Wage Determination Under Communism and In Transition: } \\
\text { Evidence from Central Europe }\end{array}$ & $\begin{array}{l}\text { Swati Basu, Saul Estrin and Jan } \\
\text { Svejnar }\end{array}$ & Aug. 2004 \\
\hline No. 716: The Evolution of Cross-Region Price Distribution in Russia & Konstantin Gluschenko & July 2004 \\
\hline $\begin{array}{l}\text { No. 715: Languages in the European Union: The Quest for Equality and } \\
\text { its Cost }\end{array}$ & $\begin{array}{l}\text { Jan Fidrmuc and Victor } \\
\text { Ginsburgh }\end{array}$ & July 2004 \\
\hline $\begin{array}{l}\text { No. 714: Voice of the Diaspora: An Analysis of Migrant Voting } \\
\text { Behavior }\end{array}$ & Jan Fidrmuc and Orla Doyle & July 2004 \\
\hline $\begin{array}{l}\text { No. 713: International Coercion, Emulation and Policy Diffusion: } \\
\text { Market-Oriented Infrastructure Reforms, 1977-1999 }\end{array}$ & $\begin{array}{l}\text { Witold J. Henisz and Bennet A. } \\
\text { Zelner and Mauro F. Guillen }\end{array}$ & July 2004 \\
\hline $\begin{array}{l}\text { No. 712: Votes and Vetoes: The Political Determinants of Commercial } \\
\text { Openness }\end{array}$ & $\begin{array}{l}\text { Witold J. Henisz and Edward D. } \\
\text { Mansfield }\end{array}$ & July 2004 \\
\hline $\begin{array}{l}\text { No. 711: Interest Groups, Veto Points and Electricity Infrastructure } \\
\text { Deployment }\end{array}$ & $\begin{array}{l}\text { Witold J. Henisz and Bennet A. } \\
\text { Zelner }\end{array}$ & July 2004 \\
\hline $\begin{array}{l}\text { No. 710: Firms' Price Markups and Returns to Scale in Imperfect } \\
\text { Markets: Bulgaria and Hungary }\end{array}$ & $\begin{array}{l}\text { Rumen Dobrinsky, Gábor Körösi, } \\
\text { Nikolay Markov, and László } \\
\text { Halpern }\end{array}$ & July 2004 \\
\hline $\begin{array}{l}\text { No. 709: The Stability and Growth Pact from the Perspective } \\
\text { of the New Member States }\end{array}$ & Gábor Orbán and György Szapáry & July 2004 \\
\hline $\begin{array}{l}\text { No. 708: Contract Violations, Neighborhood Effects, and Wage Arrears } \\
\text { in Russia }\end{array}$ & $\begin{array}{l}\text { John S. Earle and Klara } \\
\text { Sabirianova Peter }\end{array}$ & July 2004 \\
\hline $\begin{array}{l}\text { No. 707: Determinants of Employment Growth at MNEs: Evidence } \\
\text { from Egypt, India, South Africa and Vietnam }\end{array}$ & $\begin{array}{l}\text { Sumon Kumar Bhaumik, Saul } \\
\text { Estrin and Klaus Meyer }\end{array}$ & July 2004 \\
\hline $\begin{array}{l}\text { No. 706: Economic Reform in Tanzania and Vietnam: A Comparative } \\
\text { Commentary }\end{array}$ & $\begin{array}{l}\text { Brian Van Arkadie and Do Duc } \\
\text { Dinh }\end{array}$ & June 2004 \\
\hline $\begin{array}{l}\text { No. 705: Beliefs about Exchange-Rate Stability: Survey Evidence } \\
\text { from the Currency Board in Bulgaria }\end{array}$ & $\begin{array}{l}\text { Neven T. Valev and John A. } \\
\text { Carlson }\end{array}$ & June 2004 \\
\hline No. 704: Returns to Schooling in China Under Planning and Reform & $\begin{array}{l}\text { Belton M. Fleisher and Xiaojun } \\
\text { Wang }\end{array}$ & June 2004 \\
\hline $\begin{array}{l}\text { No. 703: Return to Skills and the Speed of Reforms: Evidence from } \\
\text { Central and Eastern Europe, China and Russia }\end{array}$ & $\begin{array}{l}\text { Belton M. Fleisher, Klara } \\
\text { Sabirianova Peter, and Xiaojun } \\
\text { Wang }\end{array}$ & June 2004 \\
\hline $\begin{array}{l}\text { No. 702: What Makes Small Firms Grow? F } \\
\text { Technical Assistance, and the Business Envi }\end{array}$ & $\begin{array}{l}\text { J. David Brown, John S. Earle } \\
\text { and Dana Lup }\end{array}$ & May 2004 \\
\hline $\begin{array}{l}\text { No. 701: The Effects of Multiple Minimum Wages Throughout the } \\
\text { Labor Market }\end{array}$ & $\begin{array}{l}\text { T. H. Gindling and Katherine } \\
\text { Terrell } \\
\end{array}$ & May 2004 \\
\hline No. 700: Minimum Wages, Inequality and Globalization & $\begin{array}{l}\text { T. H. Gindling and Katherine } \\
\text { Terrell }\end{array}$ & May 2004 \\
\hline No. 699: Self-Selection and Earnings During Volatile Transition & Ralitza Dimova and Ira Gang & May 2004 \\
\hline No. 698: Ecology and Violence: The Environmental Dimensions of War & $\begin{array}{l}\text { Timothy L. Fort and Cindy A. } \\
\text { Schipani }\end{array}$ & May 2004 \\
\hline $\begin{array}{l}\text { No. 697: Russian Cities in Transition: The Impact of Market Forces in } \\
\text { the 1990s }\end{array}$ & Ira N. Gang and Robert C. Stuart & May 2004 \\
\hline $\begin{array}{l}\text { No. 696: Firm Ownership and Internal Labor Practices in a Transition } \\
\text { Economy: An Exploration of Worker Skill Acquisition in Vietnam }\end{array}$ & Jed Friedman & May 2004 \\
\hline No. 695: The Unanticipated Effects of Insider Trading Regulation & $\begin{array}{l}\text { Art A. Durnev and Amrita S. } \\
\text { Nain }\end{array}$ & May 2004 \\
\hline $\begin{array}{l}\text { No. 694: Volatile Interest Rates, Volatile Crime Rates: A New } \\
\text { Argument for Interest Rate Smoothing }\end{array}$ & Garett Jones and Ali M. Kutan & May 2004 \\
\hline $\begin{array}{l}\text { No. } 693 \text { Money Market Liquidity under Currency Board - Empirical } \\
\text { Investigations for Bulgaria }\end{array}$ & $\begin{array}{l}\text { Petar Chobanov and Nikolay } \\
\text { Nenovsky }\end{array}$ & May 2004 \\
\hline $\begin{array}{l}\text { No. 692: Credibility and Adjustment: Gold Standards Versus Currenc } \\
\text { Boards }\end{array}$ & $\begin{array}{l}\text { Jean Baptiste Desquilbet and } \\
\text { Nikolay Nenovsky }\end{array}$ & 2004 \\
\hline
\end{tabular}

